O. С. Тулохонов. Рейтинговая оценка лучших территориальных общественных самоуправлений в сельских и городских поселениях Республики Бурятия

УДК 352

DOI 10.18101/2304-4446-2019-1-49-53

\title{
РЕЙТИНГОВАЯ ОЦЕНКА ЛУЧШИХ ТЕРРИТОРИАЛЬНЫХ ОБЩЕСТВЕННЫХ САМОУПРАВЛЕНИЙ В СЕЛЬСКИХ И ГОРОДСКИХ ПОСЕЛЕНИЯХ РЕСПУБЛИКИ БУРЯТИЯ
}

\author{
(C) Тулохонов Олег Сергеевич \\ кандидат экономических наук, доцент, \\ Бурятский государственный университет \\ Россия, 670000, г. Улан-Удэ, ул. Смолина, 24а \\ E-mail: oltul@mai.ru
}

Территориальные общественные самоуправления претендуют на статус точек развития институтов гражданского общества за счет интеграционных проектов улучшения локальной инфраструктуры на основе взаимодействия власти, бизнеса и местных сообществ.

В статье предлагается алгоритм подсчета рейтинга территориальных общественных самоуправлений в сельских и городских поселениях Республики Бурятия, который, в свою очередь, показывает состояние и перспективы их развития, что помогает главам органов государственной власти и местного самоуправления принимать нужные решения для активизации институтов гражданского общества.

Ключевые слова: территориальное общественное самоуправление; рейтинги; институты гражданского общества; сельские и городские поселения; Республика Бурятия.

\section{Для цитирования:}

Тулохонов $O$. С. Рейтинговая оценка лучших территориальных общественных самоуправлений в сельских и городских поселениях Республики Бурятия // Вестник Бурятского государственного университета. Экономика и менеджмент. 2019. Вып. 1. С. 4953.

В настоящее время по данным органов местного самоуправления в Республике Бурятия созданы 1702 территориальных общественных самоуправления (далее - ТОС), из них 1443 ТОСа являются активными, то есть регулярно подают заявки на участие в республиканском конкурсе и побеждают, а также дают информацию о себе и о своей деятельности в средствах массовой информации. По данному показателю в России наша республика занимает 4-е место, уступая Краснодарскому краю (5992 ТОС), Волгоградской области (1979 ТОС), Архангельской области (1915 ТОС) соответственно ${ }^{1}$. Это те регионы-лидеры, которые еще в 2010 г. поделились своим передовым опытом и дали очередной отсчет началу формирования и развития этого общественного движения в Республике Бурятия. При этом ТОСы охватывают не только сельские и городские поселения, но и городские округа Республики Бурятия: 1218 ТОСов созданы и успешно функционируют на уровне сельских поселений, 133 ТОСа - на территориях го-

${ }^{1}$ Доклад о состоянии и основных направлениях развития местного самоуправления в Российской Федерации (данные за 2017 - начало 2018 г.) //Сайт Минюста России. URL: http://minjust.ru/ru/press/news/monitoring-razvitiya-sistemy-mestnogo-samoupravleniya (дата обращения: 28.12.2018) 
родских поселений и 92 ТОСа - на территории двух городских округов (г. Улан-Удэ и г. Северобайкальск).

В определенной степени развитие территориального общественного самоуправления в Республике Бурятия получило новый импульс с приходом главы республики А. С. Цыденова, при котором был увеличен призовой фонд республиканского конкурса «Лучшее территориальное общественное самоуправление» до 60 млн рублей и принят республиканский закон от 9 мая 2018 г. № 2940-V «О государственной поддержке территориального общественного самоуправления в Республике Бурятия». Все это (наряду с другими программами и проектами федерального уровня: проект по формированию комфортной городской среды, программы поддержки местных инициатив, фонд президентских грантов) позволило укрепить и способствовать развитию не только движения территориального общественного самоуправления, но и в целом институтов гражданского общества Республики Бурятия.

На основании распоряжения Правительства Республики Бурятия «О перечне победителей и призеров республиканского конкурса "Лучшее территориальное общественное самоуправление"» мы разработали рейтинг территориальных общественных самоуправлений Республики Бурятия в сельских и городских поселениях, а также рейтинг сельских и городских поселений, в которых наиболее активно развиваются ТОСы.

Методика рейтинга «Лучший ТОС». В список были включены те территориальные общественные самоуправления, которые принимали участие и занимали призовые места в республиканском конкурсе. ТОСы ранжируются по совокупной сумме денежной премий, полученной с 2012 по 2018 г.

Таблица 1

Рейтинг ТОСов сельских поселений в Республике Бурятия (топ-20)

\begin{tabular}{|l|l|l|l|c|}
\hline № & \multicolumn{1}{|c|}{ Название ТОС } & Муниципальный район & \multicolumn{1}{|c|}{ Сельское поселение } & $\begin{array}{c}\text { Сумма } \\
\text { денежной } \\
\text { премии, } \\
\text { тыс. p. }\end{array}$ \\
\hline 1. & «Возрождение» & Тарбагатайский & Жиримское & 1080 \\
\hline 2. & «Найдал» & Кижингинский & Нижнекодунский сомон & 1020 \\
\hline 3. & «Возрождение» & Кабанский & Твороговское & 950 \\
\hline 4. & «Таежник» & Северо-Байкальский & Уоянское эвенкийское & 880 \\
\hline 5. & «арки» & Кяхтинский & Малокударинское & 810 \\
\hline 6. & «Асикта» & Северо-Байкальский & Холодное эвенкийское & 800 \\
\hline 7. & «рикто» & Баргузинский & Улюнское & 790 \\
\hline 8. & «Корсаково» & Кабанский & Корсаковское & 770 \\
\hline 9. & «Гармония» & Баунтовский & Витимское & 720 \\
\hline 10. & «Рассвет» & Курумканский & Аргада & 710 \\
\hline 11. & «лан-Еравна» & Еравнинский & Сосново-Озерское & 700 \\
\hline 12. & «Толт» & Тункинский & Толтойское & 700 \\
\hline 13. & «Возрождение» & Прибайкальский & Мостовское & 690 \\
\hline 14. & «ентральное» & Кяхтинский & Алтайское & 680 \\
\hline 15. & «озяин» & Хоринский & Удинское & 680 \\
\hline 16. & «Кючи» & Бичурский & Окиго-Ключевское & 620 \\
\hline
\end{tabular}


O. С. Тулохонов. Рейтинговая оценка лучших территориальных общественных самоуправлений в сельских и городских поселениях Республики Бурятия

\begin{tabular}{|c|l|l|l|c|}
\hline 17. & «Надежда» & Прибайкальский & Нестеревское & 610 \\
\hline 18. & «ивой ручей» & Бичурский & Дунда-Киретское & 600 \\
\hline 19. & «Надежда» & Хоринский & Ашангинское & 600 \\
\hline 20. & «Туя» & Мухоршибирский & Кусотинское & 580 \\
\hline
\end{tabular}

Источник: О Перечне победителей и призеров республиканского конкурса "Лучшее территориальное общественное самоуправление": распоряжения Правительства Республики Бурятия от 14.02.2012 г. № 70-p; от 05.04.2013 № 204-p; от 24.01.2014 № 27-p; от 15.02.2017 г. № 095-p; от 13.02.2018 № 81-p.

Таким образом, в итоговом рейтинге психологический рубеж (1 млн рублей денежной премии) преодолели только два ТОСа. Это «Возрождение» (сельское поселение «Жиримское» Тарбагатайского района) - 1080 тыс. р. и «Найдал» (сельское поселение «Нижнекодунский сомон» Кижингинского района) - 1020 тыс. р. На третьем месте уверенно расположилось ТОС «Возрождение» сельского поселения «Твороговское» Кабанского района с суммой 950 тыс. р., на четвертом месте - ТОС «Таежник» (сельское поселение «Уоянское эвенкийское» Северо-Байкальского района) с общей денежной премией 880 тыс. р. Далее плотной группой идут ТОСы «Жарки» (сельское поселение «Малокударинское» Кяхтинского района), «Асикта» и «Ярикто».

Таблица 2

Рейтинг ТОСов городских поселений в Республике Бурятия (топ-10)

\begin{tabular}{|l|l|l|l|c|}
\hline № & \multicolumn{1}{|c|}{ Название ТОС } & \multicolumn{1}{|l}{$\begin{array}{c}\text { Муниципальный } \\
\text { район }\end{array}$} & $\begin{array}{c}\text { городское поселе- } \\
\text { ние }\end{array}$ & $\begin{array}{c}\text { Сумма } \\
\text { денежной } \\
\text { премии, } \\
\text { тыс. p. }\end{array}$ \\
\hline 1. & «Плечом к плечу» & Закаменский & г. Закаменск & 750 \\
\hline 2. & «Фабричный» & Селенгинский & г. Гусиноозерск & 690 \\
\hline 3. & «Сбирячок» & Заиграевский & п. Заиграево & 610 \\
\hline 4. & «Искра» & Селенгинский & г. Гусиноозерск & 570 \\
\hline 5. & «Таежный источ- & Закаменский & г. Закаменск & 560 \\
\hline 6. & «Переулок» & Кабанский & Каменское & 550 \\
\hline 7. & «Геология» & Северо-Байкальский & п. Нижнеангарск & 550 \\
\hline 8. & «Пионерский» & Селенгинский & г. Гусиноозерск & 550 \\
\hline 9. & «Уют» & Кабанский & Каменское & 480 \\
\hline 10. & «Улыбка» & Кяхтинский & Наушкинскоее & 470 \\
\hline
\end{tabular}

Источник: О Перечне победителей и призеров республиканского конкурса "Лучшее территориальное общественное самоуправление": распоряжения Правительства Республики Бурятия от 14.02.2012 г. № 70-p; от 05.04.2013 № 204-p; от 24.01.2014 № 27-p; от 15.02.2017 г. № 095-p; от 13.02.2018 № 81-p.

Данные в таблице 2 говорят о том, что ТОСы в городских поселениях чуть менее активны и развиты, чем в сельских поселениях. Лидер среди городских 


\section{ВЕСТНИК БУРЯТСКОГО ГОСУДАРСТВЕННОГО УНИВЕРСИТЕТА}

ЭКОНОМИКА И МЕНЕДЖМЕНТ

поселений «Плечом к плечу» на порядок уступает лидерам ТОС сельских поселений.

Отличительными признаками лидеров являются: создание ТОСов с начала кампании по формированию и развитию ТОСов в Республике Бурятия, постоянное участие и призовые места в ежегодном конкурсе «Лучшее территориальное общественное самоуправление». Они успешны благодаря не только активным председателям-руководителям органов ТОС, но и членам (инициативным группам), которые непосредственно реализуют свои идеи и замыслы в жизнь, увлекая за собой новых последователей.

Методика рейтинга «Лучшее сельское поселение по развитию ТОС». В список были включены те сельские поселения, в которых зарегистрированы ТОС участники и призеры республиканского конкурса «Лучшее территориальное общественное самоуправление». Сельские поселения ранжируются по совокупной сумме денежной премии, полученной их ТОСами с 2012 по 2018 г.

Таблица 3

Рейтинг сельских поселений по развитию ТОС в Республике Бурятия (топ-10)

\begin{tabular}{|l|l|l|c|c|}
\hline № & \multicolumn{1}{|c|}{ Сельское поселение } & \multicolumn{1}{|c|}{$\begin{array}{c}\text { Муниципальный } \\
\text { район }\end{array}$} & Кол-во ТОС & $\begin{array}{c}\text { Сумма } \\
\text { денежной } \\
\text { премии, тыс. } \\
\text { руб. }\end{array}$ \\
\hline 1. & «Саянтуйское» & Тарбагатайский & 63 & 3390 \\
\hline 2. & «Краснопартизанское» & Хоринский & 11 & 2680 \\
\hline 3. & «Иволгинское» & Иволгинский & 16 & 2520 \\
\hline 4. & «Дунда-Киретское» & Бичурский & 13 & 2510 \\
\hline 5. & «Нжнекодунский сомон»» & Кижингинский & 8 & 2410 \\
\hline 6. & «Дутулурское» & Закаменский & 13 & 2340 \\
\hline 7. & «Мостовское» & Прибайкальский & 10 & 2280 \\
\hline 8. & «Аргада» & Курумканский & 11 & 2260 \\
\hline 9. & «Кижингинский сомон» & Кижингинский & 12 & 2000 \\
\hline 10. & «Улюнское» & Баргузинский & 8 & 1960 \\
\hline
\end{tabular}

Источник: О Перечне победителей и призеров республиканского конкурса "Лучшее территориальное общественное самоуправление": распоряжения Правительства Республики Бурятия от 14.02.2012 г. № 70-p; от 05.04.2013 № 204-p; от 24.01.2014 № 27-p; от 15.02.2017 г. № 095-p; от 13.02.2018 № 81-p.

Рейтинг выявил явного лидера среди сельских поселений Республики Бурятия. Это «Саянтуйское», которое буквально за последние два года из аутсайдера (127-е место в 2015 г.) вырвалось вперед. Этот успех можно объяснить активностью главы сельского поселения «Саянтуйское» муниципального образования «Тарбагатайский район» С. Ю. Шабаршовой, которая с сентября 2014 г. начала менять жизнь местного населения в лучшую сторону. Необходимо отметить, что она, успешно окончив в 2017 г. магистратуру Бурятского госуниверситета по специальности «Государственное и муниципальное управление», направила на обучение полный кадровый состав администрации «Саянтуйское» для получения передового опыта развития местного самоуправления. 
О. С. Тулохонов. Рейтинговая оценка лучших территориальных общественных самоуправлений в сельских и городских поселениях Республики Бурятия

Остальные сельские поселения, став лидерами развития ТОС в Республике Бурятия, практически с 2012 г. не уступают свои позиции. Также необходимо отметить «Селенгинский район», который благодаря деятельности главе заработал за последние 2 года более 11 млн рублей межбюджетных трансфертов.

Таким образом, в Республике Бурятия продолжает активно развиваться территориальное общественное самоуправление, в том числе благодаря государственной поддержке (финансовой, информационной, консультационной и методической). Рейтинги, свою очередь, показывают состояние и перспективы тенденции развития территориального общественного самоуправления в сельских и городских поселениях, что помогает главам органов государственной власти и местного самоуправления принимать нужные решения для активизации институтов гражданского общества.

\title{
Литература
}

1. Тулохонов О. С. Территориальные общественные самоуправления Республики Бурятия // Вестник Бурятского государственного университета. Экономика и менеджмент. 2015. № 2. С. 38-43.

2. Тулохонов О. С. Рейтинг муниципальных образований по степени развития территориальных общественных самоуправлений // Инновации и инвестиции. 2016. № 1. C. 114-118.

3. Тулохонов О. С. Оценка состояния и уровня развития территориального общественного самоуправления в Республике Бурятия // Вопросы региональной экономики. 2016. №1 (26). C. 96-102.

\section{RATING OF TERRITORIAL PUBLIC SELF-GOVERNMENTS IN RURAL AND UR- BAN SETTLEMENTS OF THE REPUBLIC OF BURYATIA}

\author{
Oleg S. Tulokhonov \\ Cand. Sci. (Econ.), A/Prof., \\ Buryat State University, \\ 24a Smolina St., Ulan-Ude 670000, Russia \\ E-mail: oltul@mai.ru
}

Territorial public self-governments claim for the status of points for development of civil society institutions through integration projects aimed at improvement of local infrastructure by interaction of government, business and local communities.

The article proposes an algorithm for calculating the rating of territorial public selfgovernments in rural and urban settlements of the Republic of Buryatia, which define the state and prospects of their development. The data received allow the heads of state and local governments to make the necessary decisions for activation of civil society institutions. Keywords: territorial public self-government; ratings; institutions of civil society. 